\title{
From Irish Exceptionalism to European Normality?: The New Islamic Presence in the Republic of Ireland
}

\section{Oliver Scharbrodt}

\section{(2) OpenEdition \\ Journals}

Electronic version

URL: http://journals.openedition.org/etudesirlandaises/3928

DOI: 10.4000/etudesirlandaises.3928

ISSN: 2259-8863

Publisher

Presses universitaires de Rennes

\section{Printed version}

Date of publication: 20 November 2014

Number of pages: $147-160$

ISBN: 978-2-7535-3559-6

ISSN: 0183-973X

Electronic reference

Oliver Scharbrodt, «From Irish Exceptionalism to European Normality?: The New Islamic Presence in the Republic of Ireland », Études irlandaises [Online], 39-2 | 2014, Online since 20 November 2016, connection on 01 May 2019. URL : http://journals.openedition.org/etudesirlandaises/3928 ; DOI 10.4000/etudesirlandaises.3928 


\title{
From Irish Exceptionalism to European Normality?: The New Islamic Presence in the Republic of Ireland
}

\author{
Oliver SchaRBRodT \\ University of Chester
}

Abstract

Due to its colonial past, Ireland has often been described as an exceptional state in Western Europe. The discourse of Irish exceptionalism also suggests a smoother path of integration for Muslim migrants compared to other Western European countries. Apart from providing an overview of Muslim immigration to the Republic of Ireland in the last 20 years, the paper critically engages with the discourse of Irish exceptionalism and discusses how Ireland's experience of colonialism shapes current discourses on the new Islamic presence in the Republic of Ireland.

Keywords: Islam, Muslims, Ireland, exceptionalism, postcolonialism

\section{Résumé}

En raison de son passé colonial, l'Irlande a souvent été décrite comme un Etat exceptionnel en Europe occidentale. Le discours fondé sur l'idée d'une exception irlandaise suggère également une voie plus aisée d'intégration pour les migrants musulmans que dans les autres pays d'Europe de l'Ouest. En plus d'une vue d'ensemble de l'immigration musulmane en République d'Irlande au cours des vingt dernières années, cet article propose une analyse critique du discours exceptionnaliste et discute la manière dont l'expérience irlandaise du colonialisme modèle les discours contemporains sur la présence islamique nouvelle en République d'Irlande.

Mots clés: Islam, Musulmans, Irlande, exceptionnalisme, postcolonialisme

Scholarship on the experiences of Muslim immigration to smaller countries at the geographical margins of Europe suggests that the dynamics that have become paradigmatic to Western European countries which have received the bulk of post-World War II Muslim immigration are only relevant to a limited extent. As patterns of immigration have differed, issues around the continuous socio-economic marginalisation of Muslim migrant communities in their new host societies, fear of an increasing Islamisation of the public sphere, the securitisation of Islam post-9/11 and public debates about the place of Muslims in Europe's liberal democracies have not gained the same degree of prominence in Ireland. It appears that the integration of Muslims in the Republic of Ireland has been a success 
story, a notion that is reiterated by representatives of major Muslim organisations, Christian churches, the media, Irish politicians and in academic scholarship to some extent as well ${ }^{1}$.

Certain factors create different dynamics in discussions of the place of Islam in Ireland: Ireland is the only postcolonial country in Western Europe; religion in the form of the Catholic Church has played a significant role in the construction of Irish nationalism and exercised immense social power in the past; a process of secularisation only began in the 1970s; Ireland's experience of multiculturalism is very recent, only beginning in the early 1990s with the economic boom leading to mass immigration to Ireland and a rapid increase of the Muslim population. As a result of these particular historical experiences, a discourse of "Irish exceptionalism" has emerged to suggest the exceptional position of Ireland within Western Europe. This discourse of exceptionalism also becomes apparent in questions of the integration of migrants in general and Muslims in particular, proposing a smoother path of integration for Muslim migrants compared to other Western European countries.

The Muslim population has grown from around from around 4,000 in the early 1990 s to almost 50,000 according to the 2011 Census. The rapid growth of the Muslim population is illustrative of the socio-cultural changes of Irish society in the aftermath of the Celtic Tiger Years (1995-2008) which turned Ireland from a country of emigration to one of immigration and transformed Ireland from a fairly homogeneous society to one that is marked by a high degree of cultural and religious diversity which challenges the traditional bi-sectarian lens of Irish religious history ${ }^{2}$. Apart from providing an overview of Muslim immigration to the Republic of Ireland in the last 20 years, the paper critically engages with the discourse of Irish exceptionalism and discusses how Ireland's experience of colonialism shapes current discourses on the new Islamic presence in the Republic of Ireland.

\section{The Discourse of Irish Exceptionalism}

Nations are "imagined communities" whose collective identities are products of discourses that are constructed, imagined and conveyed through narratives of national culture: "People are not only legal citizens of a nation; they participate

1. See Kieran Flynn, "Understanding Islam in Ireland," Islam and Christian-Muslim Relations, no. 17, 2006, p. 223-238; Tuula Sakaranaho, Religious Freedom, Multiculturalism, Islam: Cross-reading Finland and Ireland, Leiden, Brill, 2006.

2. Olivia Cosgrove at al. (eds.), Ireland's New Religious Movements, Newcastle-upon-Tyne, Cambridge Scholars Press, 2011, p. 1-4.

3. Benedict Anderson, Imagined Communities: Reflections on the Origin and Spread of Nationalism, revised edition, London, Verso, 2006. 
in the idea of the nation as represented in its national culture. A nation is a symbolic community ${ }^{4}$. This process of national identity construction utilises notions of "national uniqueness" which differentiates a nation from other nations and creates a sense of homogeneity to transcend intra-national differences and diversity. Such a relational approach to national identification processes contains the demarcation from Others that are identified as different and distinct from the nation. Anna Triandafyllidou introduces the concept of the "Significant Other" which "refers to another nation or ethnic group that is usually territorially close to, or indeed within, the national community. Significant Others are characterized by their peculiar relationship to the in-group: they represent what the in-group is not". In contemporary Europe, immigrant communities and Muslim immigrants in particular have become the "Significant Other" of European societies threatening assumptions of ethnic, cultural and national homogeneity by their racial and cultural differences.

In the Irish context, Britain as Ireland's former colonial power has historically been its external "Significant Other". Postcolonial national identity discourses have created dichotomies between Britishness and Irishness in order to recover a sense of pre-colonial "authentic" Irish identity that was lost or destroyed by British cultural penetration. Protestants and Travellers have been construed as internal "Significant Others" in Ireland. Protestants have been associated with Britishness and hence religio-culturally different and Travellers have been seen as a social group whose non-sedentary life-style and assumed ethnic difference threatens mainstream definitions of Irish identity. While Protestants have managed to thrive in "a cultural ghetto" because of their socio-economic status, Travellers have experienced significant discrimination and immense cultural and socio-economic marginalisation ${ }^{8}$.

Ireland's unique position as Western Europe's only postcolonial nation has also contributed to a sense of national uniqueness, referred to as Irish exceptionalism. It denotes the idea that Ireland is an anomaly among the nation-states of Western Europe, an anomaly that became manifest in economic underdevelopment, the

4. Stuart Hall, "The Question of Cultural Identity", Stuart Hall at al. (eds.), Modernity: An Introduction to Modern Societies, Malden and Oxford, Blackwell, 1996, p. 612.

5. Ruth Wodak, Rudolf de Cilia, Martin Reisigl, The Discursive Construction of National Identity, translated by Angelika Hirsch and Richard Mitten, Edinburgh, Edinburgh University Press, 1999, p. 27.

6. Anna Triandafydillou, "Nations, Migrants and Transnational Identifications: An Interactive Approach to Nationalism", Gerard Delanty and Krishan Kumar (eds.), The Sage Handbook of Nations and Nationalism, London, Sage, 2006, p. 286.

7. Richard Clarke, "On Doing Things Differently: A Church of Ireland Glance at the Past", Dennis Carroll (ed.), Religion in Ireland: Past, Present and Future, Dublin, The Columba Press, 1999, p. 37

8. Nathalie Rougier and Iseult Honohan, "Ireland", Ricard Zapata-Barrero and Anna Triandafyllidou (eds.), Addressing Tolerance and Diversity Discourses in Europe: A Comparative Overview of 16 European Countries, Barcelona, Barcelona Centre for International Affairs, 2012, p. 256-260. 
highest emigration rates in the European Economic Community, confessional underpinnings of the island's different national identities, a long and protracted history of ethno-religious conflict in Northern Ireland and the strong social power of the Catholic Church over public morality and clerical interventions in education and health. However, in the early $21^{\text {st }}$ century, Ireland does not appear to be that exceptional any more. The Celtic Tiger economic boom countered the historical narrative of Ireland's economic underdevelopment and turned Ireland from a country of emigration to one of immigration. Continuing and accelerating the trend that began in the 1970s, the increasing globalisation of the Irish economy and society, economic development and the revelation of clerical abuse scandals undermined the socio-cultural standing of the Catholic Church and its sway over public morality and resulted in the liberalisation of private morality and legislative changes which permit divorce or same sex marriages. The Good Friday Agreement of 1998 saw the end of the military conflict in Northern Ireland and the formation of a power-sharing government between Protestants and Catholics ${ }^{9}$.

Recent scholarship has questioned the notion of Ireland as an exception in Western Europe. Revisionist approaches to Irish history during British rule have problematised or rejected the discourse of colonial victimisation and argued that the notion of exceptionalism has been used to amplify and to internalise cultural, religious and political differences between Ireland and Britain in order to construe a postcolonial national identity. The questioning of Irish exceptionalism has gained further momentum in social science research on the socio-cultural transformation following the economic boom of the $1990 \mathrm{~s}^{10}$.

However, it appears that there still exists one area in which Ireland is exceptional. Representatives of Muslim organisations in Ireland emphasise the good cooperation between them and the Irish government and emphasise the general respect shown in Ireland for religion which has helped Muslims to seek accommodation for their cultural and religious needs in a much easier fashion compared to the rest of Europe:

Leaders of the small but growing Muslim community also speak warmly of their good relations with the Irish state and public, emphasising their preference for the respect paid to religion in Ireland compared to the secular atmosphere of a country like Great Britain ${ }^{11}$.

9. Michael Cronin, "Small Worlds and Weak Ties: Ireland in the New Century", Journal of Irish Studies, no. 22, 2007, p. 63-65.

10. Linda Connolly, “The Limits of 'Irish Studies': Historicism, Culturalism, Paternalism,” Irish Studies Review, no. 12, 2004, p. 139-162.

11. Kevin Boyle and Juliet Sheen, Freedom of Religion and Belief. A World Report, London \& New York, Routledge, 1997 , p. 348. 
The contrast created in this statement between "religious Ireland" and "secular Britain" is a striking observation, echoing notions of Irish exceptionalism and the dichotomisation between Irish and British socio-cultural identities. In the following discussion, the new Islamic presence is connected with the notion of Irish exceptionalism. After providing an overview of Muslim immigration to the Republic of Ireland from the mid-1990s, discursive spaces of Islam in Ireland in light of the country's own postcoloniality and national identity construction will be examined.

\section{Muslim Immigration in the Celtic Tiger Years}

It has become a common to mark the early to mid 1990 s as a major watershed period in Irish economic development and consequent migration patterns ${ }^{12}$. The rapid increase of the Muslim population within the last 20 years is a striking example of the major socio-economic and cultural transformations in Ireland following the Celtic Tiger Years. The Muslim population has grown substantially and also diversified ethnically and socio-economically with high numbers of labour migrants, refugees and asylum seekers ${ }^{13}$. The census data of the last four censuses, in which a question on religions have been included (1991, 2001, 2006, 2011), illustrates the massive increase of the Muslim population in Ireland similar to the increase of other faith communities comprised of migrants. While in the 1991 census 3,875 residents of the Republic of Ireland identified themselves as Muslims, the number increased to 49,204 in 2011 rising from $0.1 \%$ of the entire population to $1.1 \%{ }^{14}$.

Muslim migration to Ireland has been extremely diverse without any particular ethnic or cultural group being predominant. The census data also suggests a socioeconomic gap within the overall Muslim population which is linked to patterns of Muslim settlement in Ireland post-WWII. Sustained Muslim settlement from the 1950s until the early 1990s was made up primarily of students who came for higher education and then stayed, or those wishing to set up businesses. Thus, they had solid educational and professional backgrounds. A significant proportion of Muslims are highly qualified, possess tertiary educational degrees and work as educated professionals on higher salary scales. Ireland's economic boom since

12. Piaras Mac Éinrí and Allen White, "Immigration into the Republic of Ireland: A Bibliography of Recent Research", Irish Geography, no. 41, 2008, p. 151-179; Piaras Mac Éinrí, "Immigration: Labour Migrants, Asylum Seekers and Refugees", Brendan Bartley et al. (eds.), Understanding Contemporary Ireland, London, Pluto Press, 2007, p. 236-239.

13. Oliver Scharbrodt, "Muslim Immigration to the Republic of Ireland: Trajectories and Dynamics since World War II", Eire-Ireland: Journal of Irish Studies, no. 47, 2012, p. 221-243.

14. Central Statistics Office, Census 2011: Profile 7 - Religion, Ethnicity and Irish Travellers, Dublin, Central Statistics Office, 2012, p. 16. 
the 1990s has diversified the face of Muslim immigration. Growing numbers of Muslim asylum seekers have also arrived from Nigeria, Algeria, Libya, Sudan, Somalia and Iraq, as well as large numbers of economic migrants from across the world $^{15}$.

Table 1: Census data of selected religions 1991-2011 Source: CSO ${ }^{16}$

\begin{tabular}{|l|c|c|c|c|c|}
\hline Religion & 1991 & 2002 & 2006 & 2011 & $\begin{array}{c}\text { Percentage change } \\
2006-2011\end{array}$ \\
\hline Roman Catholic & $3,228,327$ & $3,462,606$ & $3,881,446$ & $3,861,335$ & 4.9 \\
\hline Church of Ireland & 89,187 & 115,611 & 125,585 & 129,039 & 8.6 \\
\hline Muslim & 3,875 & 19,147 & 32,539 & 49,204 & 51.2 \\
\hline Orthodox & 358 & 10,437 & 20,798 & 45,223 & 117.4 \\
\hline $\begin{array}{l}\text { Apostolicl } \\
\text { Pentecostal }\end{array}$ & 285 & 3,152 & 8,116 & 14,043 & 73.0 \\
\hline Buddhist & 986 & 3,894 & 6,516 & 8,703 & 33.6 \\
\hline Hindu & 953 & 3,099 & 6,082 & 10,688 & 75.5 \\
\hline
\end{tabular}

\section{The New Islamic Presence and Irish National Identity Discourses}

The historical memory of British colonialism in the construction of Irish nationalism and an independent Irish nation-state is present, for example, in the annual commemoration of the Easter Uprising of 1916, museums documenting the Great Famine of 1845-1852, events and exhibitions on Irish emigration in the $19^{\text {th }}$ and early $20^{\text {th }}$ century as a result of economic deprivation during British colonial rule. Such events have become markers of the postcolonial memory reflecting the degree of repression by British colonial rule and the hardship of the Irish struggle for independence. This postcolonial historical memory is often used to suggest commonalities with African and Asian countries in the shared historical experience of colonial subjugation by British and European imperialism. In the late $19^{\text {th }}$ and early $20^{\text {th }}$ centuries, Irish nationalists were part of a global network of anti-colonial activists including Egyptian, Indian and Iranian nationalists ${ }^{17}$ connections that buttress Irish postcolonial credentials. The young Irish republic

15. Oliver Scharbrodt, op. cit., p. 221-243.

16. Central Statistics Office, Census 1991: Vol. 5 Religion, Dublin, Central Statistics Office, 1995, p. 22. Central Statistics Office, Census 2006: Volume 13 - Religion, Cork, Central Statistics Office, 2007, p. 23. CSO, Census 2011: Profile 7, p. 48.

17. Mansour Bonakdarian, "Erin and Iran Resurgent: Irish Nationalists and the Iranian Constitutional Revolution”, Houchang E. Chehabi and Vanessa Martin (eds.), Iran's Constitutional Revolution: Popular Politics, Cultural Transformations and Transnational Connections, London, I.B. Tauris, 2010, p. 291-318; Rozina Visram, Ayahs, Lascars and Princes: Indians in Britain, 1700-1947, London, Pluto Press, 1986, p. 77-110. 
exhibited a strong "Third-World" orientation being involved in anti-apartheid initiatives in the South African context and exhibiting a strong pro-Palestinian stance $^{18}$.

As a consequence, the historical complexities shaping the relationship of Muslims to wider society in countries such as Britain or France based on their colonial past are not present. On the contrary, it appears that Ireland's postcoloniality aligns it with other former colonies in Africa and Asia and separates it from the imperialist history of the rest of Europe. Interviews with representatives of Muslim organisations have highlighted a historical experience of colonial subjugation shared between Muslims and Irish: "What the Irish experienced by the British is much worse than what we Muslims experienced during colonialism ${ }^{19}$." The choice to launch the European version of the Hijabi Monologues, an American theatre project that brings stories of Muslim women on stage, in Ireland was based on the argument "that Ireland is uniquely positioned to host the European premiere - unlike the historical relationships European Muslim minorities have had with other EU nations and colonialism, Ireland does not have the same history with its Muslim communities and new immigrants ${ }^{20}$ ".

Analogies are also drawn between nationalist aspirations in other countries and the Irish struggle for independence. In an opinion piece, written by the clerical leader of the Iraqi Shii community in Ireland, to justify the American invasion of Iraq and the toppling of Saddam Hussein in 2003, a historical parallel is created between the aspirations of the Iraqi people and the struggle for Irish independence in the early twentieth century: "Iraqis today want what the Irish wanted in 1922: to live in peace, to rule ourselves, to raise our children according to the traditions of our religious faith and to be free of foreign oppressors ${ }^{21}$." The overall pro-Palestinian stance of the Irish government is presented as constituting a different relationship between the Irish state and society and Muslims. As a major cause for global Muslim grievance, Muslims find in the Irish an ally supporting their cause, as they are perceived as "'almost unique'... in the West in their sympathy with the Palestinians ${ }^{22}$ ".

In light of European debates around the place of the Islamic headscarf in the public sphere and legislation in some European countries to ban it from public

18. Rory Miller, "The Politics of Trade and Diplomacy: Ireland's Evolving Relationship with the Muslim Middle East”, Irish Studies in International Affairs, no. 15, 2004, p. 123-145.

19. Author's interview with Yahya Al-Husayn, 10 June 2009.

20. Sahar Ullah, "Column: Muslim women face all kinds of assumptions. Let's look behind the headscarves", The Journal.ie, 25 March 2012, available at [http://www.thejournal.ie/readme/column-muslim-women-face-allkinds-of-assumptions-let\%E2\%80\%99s-look-behind-the-headscarves-393986-Mar2012/\#comments], accessed 26 February 2014.

21. Dr Ali Al Saleh, "What Future do Iraqis want?", The Irish Times, 18 March 2006, p. 15.

22. Andy Pollock, "Just another chapter of Muslim suffering”, The Irish Times, 19 January 1991, p. 13. 
schools, one contribution creates a causal connection between Irish colonial experience and a different attitude of Irish society towards other cultures. The article argues that current negative views on Muslim minorities in Europe and their construction as Europe's internal "Significant Other" have their roots in historical notions of European cultural superiority which shaped the continent's encounter with other cultures in the colonial age and served as a rationale to legitimise European imperialism. However, Ireland as Western Europe's only postcolonial nation is unique in this regard:

Ireland is exceptional among the EU member states because for centuries it experienced colonialism from the perspective of the colonised. While this history remains tragic, today it gives the country a unique position in Europe. Not only could this experience help Ireland to accommodate the growing cultural diversity in its own society; it also enables the country to play a leading role in redefining the European stance towards other cultures ${ }^{23}$.

This line of argumentation connects Irish exceptionality with a European mission; Ireland not only is better prepared to cope with its new internal diversity, it should also lead the rest of Europe towards embracing a different attitude towards the cultures and societies of formerly colonised nations.

These discursive references to Ireland's colonial past suggest "that there is a huge amount of historical and traditional commonalities between Muslim immigrants and the Irish natives ${ }^{24}$ ". In addition, with the increasing importance of commemorating the Great Famine of 1845-52, efforts have been made to connect this paradigmatic tragedy of colonial Ireland with Muslim relief efforts at that time. Apart from Queen Victoria and some native American tribes, the Ottoman Sultan 'Abdül-Mecid I (1823-61) donated $£ 1,000$ (after being dissuaded by Queen Victoria from donating more) and secretly sent three or five ships with food aid to Ireland which could unload at the port of Drogheda in $1847^{25}$. In several Muslim web blogs, this episode is seen as an example of "Turkish-Irish friendship ${ }^{26 "}$, showing "how Muslims helped Ireland during the Great Famine ${ }^{27}$ "

23. Jakob de Roover, "No point in banning headscarves and turbans", The Irish Times, 19 June 2008, p. 16.

24. Ali Selim, "Integration of Muslims in Ireland", Spectrum, no. 9, July 2005, p. 28.

25. Antoinette Kelly, "New evidence shows Turkey delivered food to Ireland during the famine", IrishCentral, 2 June 2012, available at [http://www.irishcentral.com/news/new-evidence-shows-turkey-delivered-food-to-irelandduring-the-famine-156681255-237507681.html], accessed 26 February 2014; "The Great Irish Famine and Ottoman Humanitarian Aid to Ireland, The Pen, 30 December 2011, available at [http://www.thepenmagazine. net/the-great-irish-famine-and-the-ottoman-humanitarian-aid-to-ireland/], accessed 26 February 2014.

26. Jawad Yaqub, "How quickly we forget", Razormind, 6 August 2013, available at: [http://www.razormind.co.uk/ how-quickly-we-forget-how-muslims-helped-ireland-during-the-great-famine/], accessed 26 February 2014.

27. Mehdi Islam, "How Muslim helped Ireland during the Great Famine", archive:islam, 28 March 2013, available at [http://archiveislam.com/how-muslims-helped-ireland-during-the-great-famine.html], accessed 26 February 2014. 
and explaining why "the Irish people, especially those in Drogheda, are friendly to the Turks ${ }^{28 "}$. To honour the contribution of the Ottoman Sultan, the football club Drogheda F.C. apparently adopted the star and crescent as part of its coat of $\operatorname{arms}^{29}$.

These historical dynamics in relation to the Irish colonial experience appear to open up opportunities for a different rapport between Irish society and Muslim migrants. The discourses brought forward serve different purposes; they suggest a special rapport between the Irish and Muslims, facilitating an easier integration and acceptance of Muslims in Irish society because historical colonial barriers and their postcolonial continuities between Muslim migrants and their European host societies do not exist ${ }^{30}$. Muslims cannot be construed as the "Significant Other" of Irish national identity, because both groups share too much in common to be opposed to each other. In addition, Ireland's postcolonial credentials, its tradition of neutrality and military non-intervention and pro-Palestinian stance provide little opportunity for young Muslims to be antagonised to the Irish state and to be lured by radical Islamic discourse ${ }^{31}$. This explains the weak securitisation of Muslims in Ireland as compared to other Western European countries ${ }^{32}$ The recently discovered anecdote of Turkish relief aid during the Irish famine though not entirely factual - is supposed to create a space for Muslims in the Irish postcolonial memory of the Great Famine.

However, the postcolonial memory of victimisation and nationalist struggle of Ireland obscures the actual complicity of certain segments of Irish society in British imperialist endeavours. A more balanced reading of Ireland's postcoloniality needs to pay attention to the ambivalent position of Ireland in the British Empire: "Given that the colonial moment was, and the imperial moment is, determinative of the cultural and political identities of twentieth-century peoples, Ireland is doubly hybrid, subject and object of the process ${ }^{33}$." The supporters of Home Rule in the late $19^{\text {th }}$ century, for example, did not refer to Ireland as a colony but pointed at the Irish contribution to the imperial project in order to

28. "How the Khilafah aided the Irish during the famine of 1845", Khilafah.com: Building a global movement for Khilafah, 30 December 2007, available at [http://www.khilafah.com/index.php/the-khilafah/non-muslims/1586how-the-khilafah-aided-the-irish-during-the-famine-of-1845], accessed 26 February 2014.

29. The star and crescent as part of Drogheda's coat of arms pre-date the famine going back to 1210 . Ken Murray, "President tells Turks an anecdote of myth not fact", The Irish Times, 25 March 2010, p. 11.

30. For a discussion of this continuity in the context of Britain, see Maleiha Malik, "Angare, the 'Burning Embers' of Muslim Political Resistance: Colonial and Post-colonial Regulation of Islam in Britain”, Marcel Maussen et al. (eds.), Colonial and Post-Colonial Governance of Islam: Continuities and Ruptures, Amsterdam, Amsterdam University Press, 2011, p. 199-209.

31. Sardar Aziz, "No Identity Please: On Integration of Muslims in Ireland", Irish Journal of Public Policy 4:1 (2012), available at: [http://publish.ucc.ielijpp/2012/01/AzizSardar/05/en], accessed 26 February 2014.

32. Nathalie Rougier and Iseult Honohan, op. cit., p. 269.

33. James Livesey and Stuart Murray, "Review Article: Postcolonial Theory and Modern Irish Culture", Irish Historical Studies, no. 30, May 1997, p. 461. 
justify Home Rule. Many Home Rule MPs were personally involved in colonies with various business interests and not opposed to British imperialism outside of Europe as such. While they denounced British colonial excesses in Africa and Asia, they also considered Canada or Australia as examples of how autonomy can be achieved within the Empire ${ }^{34}$. The racialisation of anti-colonial discourse also becomes evident in notions that the very whiteness of the Irish is the reason why they should be independent ${ }^{35}$.

Irish anti-colonial struggle is therefore marked by a particular ambivalence. On the one hand, it is based on an anti-British and anti-imperialist ideology which shaped Irish national identity formation after independence and resulted in Ireland's support for the anti-colonial struggles of African and Asian nations. On the other hand, it is also based on a mono-cultural understanding of Irish identity as defined by birth and ethnicity, Gaelic language and culture, Catholicism and the predominantly rural life of Ireland which need to be defended against foreign intrusion and cultural penetration ${ }^{36}$. While Ireland's postcoloniality is used to suggest a more accommodating environment for Muslim migrants, the ambivalence of the Irish colonial experience can also result in a more defensive stance of an Irish society whose mono-cultural self-perception is increasingly challenged by mass immigration. The 2004 Citizenship Referendum gives an illustration of this protectionist element of Irish national identity.

Mass immigration to Ireland has led to an increasing visibility of racist attitudes in Irish society ${ }^{37}$. The inadequate regulation of immigration and the fairly easy access to Irish citizenship triggered the Irish Citizenship Referendum of 2004 in whose course public debates tapped into concerns about mass immigration, the dilution of Irish ethno-cultural homogeneity and the abuse of welfare benefits by immigrants and asylum seekers ${ }^{38}$. Prior to the 2004 referendum, three pathways existed to citizenship of the Republic of Ireland: Irish descent (through a grandparent), residence or birth. After 2004 only descent and residence have remained, based on the notion that birth on Irish soil alone does not warrant granting Irish citizenship but that those who obtain it need to a have a sufficient link

34. Pauline Collombier-Lakeman, "Ireland and the Empire: the Ambivalence of Irish Constitutional Nationalism”, Radical History Review, no. 104, Spring 2009, p. 57-76.

35. Piaras Mac Éinrí, “'A Slice of Africa’. Whose Side Were We on? Ireland and the Anti-colonial Struggle?”, Alana Lentin and Ronit Lentin (eds.), Race and State, Newcastle-upon-Tyne, Cambridge Scholars Publishing, 2006, p. 262-272.

36. Nathalie Rougier and Iseult Honohan, op. cit., p. 250-252.

37. Steve Garner, "Ireland and Immigration: Explaining the Absence of a Far Right", Patterns of Prejudice, no. 41, 2007, p. 109-130.

38. Bernard Ryan, "The Celtic Cubs: The Controversy over Birthright Citizenship in Ireland”, European Journal of Migration and Law, no. 6, 2004, p. 173-193; Gerry Boucher, "The Entrenchment of Ireland's Laissez-Faire Integration Policy", Translocations: Migration and Social Change, no. 6, 2010, available at [http://www.translocations.ie/v06i02.html], accessed 3 March 2014. 
with Ireland either by descent or residence. The legislation moved from ius solis to ius sanguinis as descendants of Irish living outside of Ireland receive preferential treatment when applying for Irish citizenship ${ }^{39}$. Racialised notions of Irishness were upheld by mainstream political parties with their own postcolonial historical baggage of fighting for the country and soil and defending it against foreign intrusion $^{40}$.

Citizenship was also conceived in neo-liberal terms. The close monitoring of immigration was legitimised in terms of economic benefits and to prevent welfare fraud by immigrants and asylum seekers. Because of this neo-liberal migration regime, arguments of the pro-referendum campaign did not utilise notions of cultural foreignness to restrict access to citizenship but presented citizenship as a kind of commodity which rewards hardworking immigrants for their contributions to Irish society and economy. Hence, anti-immigration discourse did not pay much attention to the cultural and religious backgrounds of immigrants ${ }^{41}$. A real Islamophobic discourse did not emerge and was not picked up by any of the political party and in wider public discourse before the Citizenship Referendum and afterwards.

However, with the growing numbers of Muslims living in Ireland and their increased visibility in the public sphere, discourse have emerged that echo antiMuslim sentiments across Europe. Representatives of Muslim organisations often refer to the Irish "respect for religion" as creating an environment that is more accommodating than the more secular societies of other Western European countries $^{42}$. Reference is made to the unproblematic establishment of two publicly-funded, faith-based Muslim primary schools in Dublin which went ahead without any bureaucratic complications or public outcry ${ }^{43}$. Debates around the permissibility of the Islamic headscarf in public schools have not gained the prominence in Ireland as they have elsewhere in Europe. There is a sense that "a number of issues, e.g. food, prayer, hijab... are usually sorted out easily ${ }^{44}$ " when Muslim pupils enter schools.

In 2008, Ireland experienced its own minor headscarf affair when the principal of a secondary school in Co. Wexford referred a Muslim parent's enquiry whether his daughter was allowed to wear the headscarf to the Department of Education

\footnotetext{
39. Steve Garner, op. cit., p. 124-126.

40. Ibid., p. 128-129.

41. John A. Harrington, "Citizenship and the Biopolitics of Post-Nationalist Ireland", Journal of Law and Society, no. 32, September 2005, p. 447.

42. Tuula Sakaranaho, op. cit., p. 270-273.

43. Tuula, Sakaranaho, “For God and Eternal Values': Muslim National Schools in Ireland”, Ednan Aslan (ed.), Islamische Erziehung in Europa. Islamic Education in Europe, Vienna, Böhlau, 2009, p. 203-218.

44. Ali Selim, op. cit.
} 
and Skills ${ }^{45}$. The guidelines provided by the Department remained rather vague leaving it up to individual schools to decide on which policy to adopt with regards to the hijab ${ }^{46}$. In the course of the public debate following this incident, the hijab was presented as "a symbol of repression and submission" 47 ", as having "an element of male domination over females ${ }^{48}$ ", as expressing "a refusal to integrate ${ }^{49}$ " and as

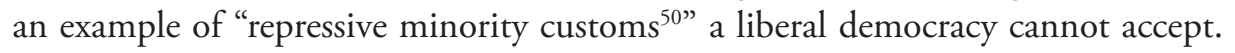
Ruairi Quinn, at that time Labour spokesperson for education and since 2011 Minister for Education and Skills, stated that the hijab conflicts with "the rules and regulations" of "a Western society that is Christian and secular ${ }^{51}$ ", echoing similar discourses across Europe which see wearing the headscarf as a sign to assert Muslim identity and as a challenge to a secularised cultural Christian identity of Europe ${ }^{52}$.

While most Irish schools allow Muslim girls to wear the hijab, a recent case in which a Muslim girl was not allowed to wear it when enrolling at a secondary school in Dun Laoghaire ${ }^{53}$ illustrates the uncertainty around this issue and the prevalence of views that deem the hijab as having no place in Irish society. Instances have been reported of Muslim women who had to remove their headscarf when their photos were taken for residence permits that are issued by the Garda $^{54}$. A Lithuanian Muslim convert, employed at Dunnes Stores, opened a case for unfair dismissal in 2012 as she was not permitted to wear hijab at work ${ }^{55}$. A recently concluded research project has found out that Muslim women in Ireland wearing the headscarf are more prone to be victims of anti-Muslim verbal

45. Stacey Scriver, "Ireland through the Veil: Gender, Autonomy and the Nation", Gender, Empowerment and Globalisation Research Cluster, Working Paper no. 4, 2010, p. 1-31.

46. Claire Hogan, "Accommodating Islam in the Denominational Irish Education System: Religious Freedom and Education in the Republic of Ireland", Journal of Muslim Minority Affairs, no. 31, December 2011, p. 556-557.

47. Martina Devlin, "If Muslim men like the veil so much, let them wear it", Irish Independent, 22 May 2008, available at [http://www.independent.ielopinion/columnists/martina-devlin/if-muslim-men-like-the-veil-so-muchlet-them-wear-it-26449388. html], accessed 3 March 2014.

48. Ruadhán Mac Cormaic, "Looking beyond the headscarf", The Irish Times, 14 June 2008, p. 1.

49. Ibid.

50. Sinead Ryan, "An insult to our values", Herald, 23 May 2008, available at [http://www.herald.ielopinion/columnists/sinead-ryanlan-insult-to-our-values-27874531.html], accessed 3 March 2014.

51. Patricia McDonagh, "Muslim anger at opposition calls for school ban on hijab", Irish Independent, 2 June 2008, available at [http://www.independent.ie/irish-news/muslim-anger-at-opposition-calls-for-school-ban-onhijab-26451464.html], accessed 3 March 2014.

52. Valérie Amiraux, "The Headscarf Question: What is Really the Issue?”, Samir Amghar et al. (eds.), European Islam: Challenges for Public Policy and Society, Brussels, Centre for European Policy Studies, 2007, p. 124-143.

53. Shaun Connolly, "Quinn refuses to intervene in veil ban", Irish Examiner, 16 August 2013, available at [http:// www.irishexaminer.com/ireland/quinn-refuses-to-intervene-in-veil-ban-240039.html], accessed 20 January 2014.

54. Mary Fitzgerald, "Muslims asked to remove headscarves for new garda card", The Irish Times, 21 March 2012, p. 3.

55. Georgina O’Halloran, "Dunnes told Muslim worker she couldn't wear her hijab”, Irish Independent, 12 September 2012, available at [http://www.independent.ie/irish-news/dunnes-told-muslim-worker-she-couldnt-wearher-hijab-26897009.html], accessed 20 January 2014. 
and physical assaults than Muslim women who do no wear it or Muslim men whose religious identity is not openly displayed ${ }^{56}$.

There has been increasing opposition to mosques in Ireland, usually related to traffic and planning issues. In Cork, a new mosque on a busy road close to the city centre in 2013 faced opposition of residents in the neighbourhood who complained of traffic and noise disruptions and violations of the original planning permission ${ }^{57}$. Similar objections were also raised to a mosque in Galway which is currently under construction ${ }^{58}$. In the run up to granting planning permission for the large mosque complex planned in Clongriffin, North Dublin, a local politician opposed the size of the development, arguing it does not meet local development plans ${ }^{59}$. While such opposition to mosque projects was rare in Ireland in the past, with the growing number of mosques and their increasing visibility, public debates around mosque construction have risen, mirroring similar debates in other European countries. While disguised in bureaucratic jargon with references to planning permissions, noise and traffic etc., these debates reveal a growing unease with the increasing visibility of Islamic religious practices in the public sphere across Europe ${ }^{60}$.

\section{Conclusion}

The racialisation of Irish national identity and citizenship which came to the fore during the Citizenship Referendum of 2004 is not just a by-product of the Celtic Tiger and a consequence of large-scale immigration but dates back to postcolonial ethno-national definitions of Irishness as based on descent, Catholicism and Gaelic culture which emerged in contradistinction to Britishness ${ }^{61}$. Muslim immigrants and converts pose a particular challenge to Irish national identity as standing outside of conventional definitions of Irishness because of their different race, culture and religion. Such racialised notions of Irish identity have become

56. James Carr and Amanda Haynes, "A Clash of Racialisations: the Policing of 'Race' and Anti-Muslim Racism in Ireland”, Critical Sociology, July 2013, as doi: 10.1177/0896920513492805.

57. Eoin English, "Planners in row over Cork city Islamic centre", Irish Examiner, 18 September 2013, available at [http://www.irishexaminer.com/ireland/planners-in-row-over-cork-city-islamic-centre-243372.html], accessed 15 January 2014.

58. Enda Cunningham, "Planners say Muslim group misled them over numbers at Galway mosque", Connacht Tribune, 19 August 2013, available at [http://www.connachttribune.ie/galway-news/item/1115-planners-say-muslim-group-misled-them-over-numbers-at-galway-mosque], accessed 15 January 2014.

59. Colette Colfer, "Ireland's largest mosque gets approval from An Bord Pleanála", The Irish Times, 29 August 2013, available at [http://www.irishtimes.com/news/social-affairs/religion-and-beliefs/ireland-s-largest-mosque-getsapproval-from-an-bord-plean\%C3\%A1la-1.1509586, accessed 15 January 2014.

60. See special issue on "Mosque Conflicts in Europe", Journal of Ethnic and Migration Studies, no. 31, 2005, p. $1015-1183$.

61. Gavan Titley, "Everything Moves? Beyond Culture and Multiculturalism in Irish Public Discourse", The Irish Review, no. 31, Spring - Summer 2004, p. 11-27. 
manifest in anti-Muslim racism which a recent research project has just begun to document ${ }^{62}$. Yet, in immigration debates in Ireland, Muslims have not emerged as Ireland's internal "Significant Other", contrary to discourses that have been observed in other Western European countries.

A recent Islamophobic letter campaign in whose course threatening letters were sent to Muslim communities, organisations and individuals ${ }^{63}$ illustrates the presence of anti-Muslim attitudes and their potential and actual violent expressions in Ireland. Emergent discourses around the headscarf, the construction of mosques and the overall place of Islam in Irish society give an indication that discourses around Ireland's new Islamic presence are similarly framed and influenced by pan-European discourses and perceptions. In this sense, Ireland is moving from Irish exceptionalism to European normality in its discursive approaches to its new Islamic presence. Further complicating predicaments lie in the very late experience of cultural, ethnic and religious diversity in Irish society and a lacking state and public engagement with the issue of racism in general and as directed against Muslims in particular ${ }^{64}$. As Ireland has lost is exceptional status post-Celtic Tiger vis-à-vis Britain and the rest of Europe, it has become more prone to antiMuslim discourses which locate Europe's "Significant Other" within its growing Muslim population.

62. James Carr and Amanda Haynes, op. cit.

63. Fiona Dillon and Tom Brady, 'Muslims target in "Hate Mail” campaign', Irish Independent, 26 November 2013, available at [http://www.independent.ie/irish-news/muslims-targeted-in-hate-mail-campaign-29783626. html], accessed 13 January 2014.

64. James Carr and Amanda Haynes, op. cit. 